\title{
Marianus Scholasticus' APl 201. A Christian rewriting of Eros from Justin II and Sophia's reign ${ }^{1}$
}

\author{
Carlos A. Martins de Jesus ${ }^{2}$
}

Recibido: 30 de noviembre de 2016 / Aceptado: 29 de diciembre de 2016

\begin{abstract}
The aim of this paper is to perform a deep analysis of $A P l$ 201, a five-couplet epigram ascribed in all manuscripts to the almost unknown Marianus Scholasticus. When describing a work of art also unidentifiable, the poet progressively transforms the Eros he (probably) sees in the image of the Christian saviour, by means of a cautious wordplay and a symbolic re-signification of the pagan attributes of that god. Furthermore, some connections between Marianus' other epigrams and the reign of Justin II and his wife Sophia's, particularly the last one, come to suggest a commissioned relation of the poet with the imperial couple, in relation to an intentional advertising propaganda that aimed to promote both of them to icons of orthodoxy in the second half of the sixth century AD.
\end{abstract}

Keywords: Marianus Scholasticus; Eros; Platonic love; Jesus Christ; Sophia.

\section{[es] Mariano Escolástico, $A P l$ 201. Una interpretación de Eros en el reinado de Justino II y Sofia}

Resumen. El presente artículo analiza en profundidad el texto de $A P l$ 201, epigrama de cinco dísticos elegíacos atribuido en todos los manuscritos al casi desconocido Mariano Escolástico. Al describir una obra de arte que tampoco logramos identificar, el poeta progresivamente reconfigura el Eros, que (probablemente) contempla, a la imagen del Salvador de los Cristianos, por medio de un cuidado juego de palabras y de la re-significación simbólica de los atributos paganos de dicho dios. Además, algunas relaciones entre otros epigramas atribuidos al mismo Mariano y el gobierno de Justino II y su mujer Sofía - en especial la última - sugieren una relación de patronato entre el poeta y la pareja imperial en el contexto de una propaganda publicitaria intencional que buscaría promover ambos a íconos de la ortodoxia religiosa de la segunda mitad del siglo vi d.C.

Palabras clave: Mariano Escolástico; Eros; amor Platónico; Jesucristo; Sophia.

Contents. I. Text and iconography. II. Eros philosophus and Christ: yet another Christian rewriting of Plato. III. Marianus, Justin and Sophia's wisdom.

How to cite: Martins de Jesus, C. A. (2017) Marianus Scholasticus' APl 201. A Christian rewriting of Eros from Justin II and Sophia's reign, en Cuadernos de Filología Clásica. Estudios griegos e indoeuropeos 27, 147-162.

1 This paper is the result of research funded by a Postdoctoral Scholarship provided by the Fundação para a Ciência e Tecnologia (Government of Portugal, Ref. SFRH/BPD/84291/2012), in collaboration with the Project Greek manuscripts in Spain and their European context (Government of Spain, Ref. FFI2011-25805).

2 UI\&D Centro de Estudos Clássicos e Humanísticos, University of Coimbra.

Fundação para a Ciência e a Tecnologia, Government of Portugal.

E-mail: carlosamjesus@gmail.com 


\section{Text and iconography}

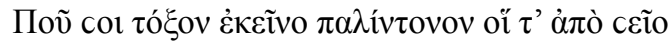

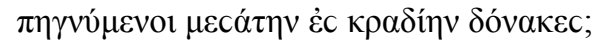

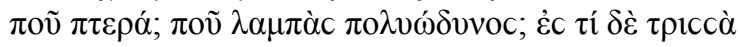

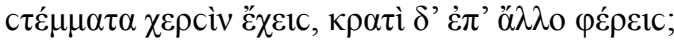

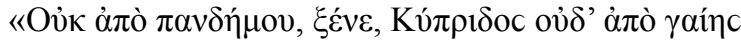

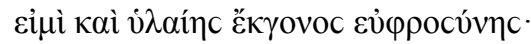

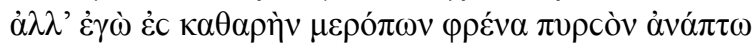

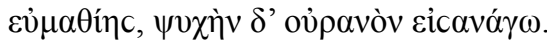

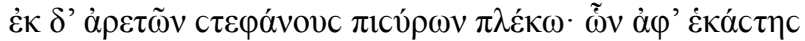

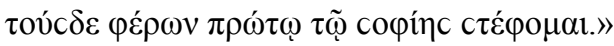

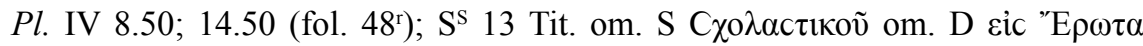

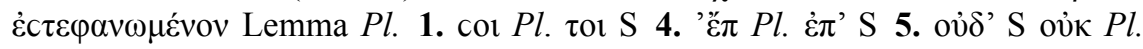

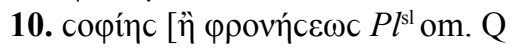

- Where is your back-stretched bow, where are your arrows, the ones you stuck right in the middle of the heart?

Where are your wings? Your many-sorrows torch, where is it?

What are those three garlands for, one already on the head?

- I truly am no son of the crossroads' Cypris, I am not from earth,

I am not even the offspring of any everyday pleasure.

I am the one who lights up in the pure hearth of mortals the flame of true-knowledge, the one who leads the soul into the sky.

I weave the garlands of four Virtues! And as I carry one for each, right now I crown myself with the first, that of Wisdom.

Only the Planudean Anthology transmits the above-printed epigram, placed as number 201 in modern editions and ascribed, with other five poems ( $A P$ 9.626, $627,657,668$ and 669), to a so-called Marianus Scholastichus. The aim of this paper is to examine the evidences that allow us to look at this Marianus, called 'Scholastichus' by Planudes and probably Agathias, as an epigrammatic poet commissioned by the imperial couple Justin II and Sophia (565-574 AD) -particularly Sophia -, an artist that performed in $A P l 201$ an allegorical encomium of that empress, meant to present her -and with it the imperial couple - as a role-model of orthodoxy.

Copied in fol. 48r of Planudes' autograph (Marcianus gr. 481), the poem is first found in section IV of that anthology, i.e., in between the large collection of $\dot{\varepsilon} \kappa \varphi \rho \alpha ́ c \tau \iota \kappa \alpha$, more specifically among a group of poetic descriptions of works of art on Eros. Right before, Planudes copied several epigrams on the model of the chained $\operatorname{Eros}^{3}$ (e.g. $A P l .195-199$ ) and another one on the farmer-type of that god (APl. 200); and right after, several epigrams on the famous Eros Praxiteles built for

3 The same is found in AP 5.179 (of Meleager). A group of Hellenistic and Roman gems portray the same model, besides the well-known fresco at the House of Cupid in Pompeii (first cent. AD). In the last example, Eros is also deprived of his weapons, while being tied up by Aphrodite. 
the Thespians, an actual and long-living statue $e^{4}$. Therefore, it is only fair to assume that also $A P l 201$ must had a relation to a common (or at least identifiable) graphic model of the god, one held somewhere in Constantinople in a way that Marianus could have seen him and compose poetry on it.

Still, no work of art possible to associate with the epigram survived, even if the relation of Eros (and Aphrodite) with garlands is indeed part of an old literary and iconographic tradition. Furthermore, the poet makes no mention of the artist or even denunciates his technique by means of any word, as it is common in Hellenistic and Byzantine ecphrastic epigrams ${ }^{5}$. Therefore, one cannot even say if Marianus is referring to an ancient statue -from the many ones we know to have been transferred and held in Constantinople during the first centuries of Byzantium ${ }^{6}-$, a painting or a mosaic. A possibility would be the reference to a late-imperial Roman sarcophagus, a kind of art fond of the presence of Eros (among other deities) and heavy garlands for its decoration ${ }^{7}$. PLATE I collects three samples, all of them united by the way they portray Eros as a child. Different from the artefact described by Marianus, Fig. 2 and 3 still keep some of the traditional attributes of the god, as the torch (in the first one) and the wings (in both of them). As for Fig. 1, one of the best examples we possess of the so-called Western-garland type of sarcophagus ${ }^{8}$, the repeated child-figure in between the garlands has in fact no wings, torch or any other traditional attribute, as in the epigram. Nonetheless, nothing surely identifies it with Eros, being one of the many examples of putti that used to decorate this kind of sarcophagi. What I am saying is that the absence of the wings and the torch, strange as they are to the first speaker of the epigram, could actually be explained if Marianus had in mind an artefact depicting this kind of child, itself a derivation of the Eros-child model.

The anonymous $\mathrm{APl} 202$, considered already by Boissonade (in Dübner 1872: 627) a different poem on the same work of art, and by Aubreton-Buffière (1980, repr. 2002: 157) a parody of Marianus' epigram, must be taken into account when looking for the epigram's graphic model or at least inspiration. In that poem, after

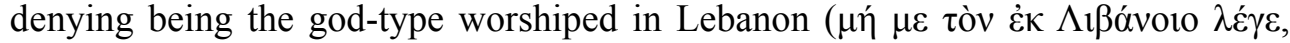

4 Praxiteles built a monumental-sized Eros to be held and worshiped in the agora of Thespiae. We know this statue was later brought into Rome by Caligula and returned to the Thespians by Claudius, coming back to Rome once again during Nero's reign, where it was finally destroyed by the fire of $80 \mathrm{AD}$ (cf. Strab. 9.2.25; Paus. 9.27.2; Plin. 36.22). After Pfrommer (1980), scholars assume this Eros type (and not the Centocelle Eros) as the Eros of Thespiae must be related to.

5 On the main characteristics of ecphrastic epigram see Männlein-Robert (2007: 251-271).

6 From Constantine I onwards, the new capital of the Empire was progressively filled with what was considered "classical art" (i.e. pre-Byzantine), both by means of accumulation of war spolia and the simple transfer of works of art from one site of the Empire to another. A paradigmatic and well-known example is the sculptural gallery held at the Baths of Zeuxippus, first organized in preparation for Constantinople's official dedication and increased by the successive emperors, of which we have a poetic description in book two of the Greek Anthology. On it, see Martins de Jesus (2014: 15-30). For an overview of the socalled classical art held at the city, from its foundation through the sixth-century reign of Justinian, see Bassett (2004).

7 Not only sarcophagi depicted Eros and garlands, as both of them seem to have become a common motif of Roman imperial arts in general. One example, actually older, could be the Eros with garlands of Fig. 4, a fresco from the House of the Trojan Sacellum in Pompeii (second style, ca. 80-20 BC), alongside the fragment of a marble frieze showing the boy Eros with two large garlands of flowers and fruits (Fig. 5), probably from the Forum of Trajanus (ca.113-117 AD).

$8 \quad$ Cf. Toynbee (1934: 202 ff.). 


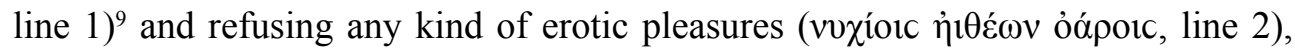
Eros claims to be a shepherd, the son of a nymph that picks up flowers to weave his (equally) four garlands. If so, the allegory of Eros would be a goal of either epigrammatists, or at least Marianus, and latter accepted by the anonymous author of $\mathrm{APl} 202$, thus giving more credit to Aubreton-Buffière's hypothesis. Furthermore, the absence of any mention to a specific garland in number 202 could prove that both the obsession with sophia and the implied identification of Eros as Christ were a product of Marianus' allegorical (and compromised) reading, not a feature somehow visible in the work of art.

Opposite to the little amount of modern commentaries devoted to Marianus' epigram, it must have been widely known at least since the sixteenth century, due particularly to Alciato's Emblemmata, where it is mistakenly interpreted as a representation of Anteros (number 60, s.v. ANTEP $\Omega \Sigma$ id est AMOR VIRTVTIS), himself a son of Aphrodite created in revenge for Eros' painful actions to mankind. But the other Eros of $A P l 201$ cannot be Anteros, as this deity is said, in two other epigrams of the Greek Anthology (APl 251-252) and other ancient sources ${ }^{10}$, to be a perfect twin-replica of the first-born god of Love, i.e., with the same iconographic attributes. Number 60 of Alciato's collection of woodcuts (PLATE II) is therefore no more than an illustration of the poem, by means of its ecphrastic characteristics -in a word, the reverse path followed by Marianus ${ }^{11}$.

\section{Eros philosophus and Christ: yet another Christian rewriting of Plato}

$A P l 201$ stages the dialogue between an anonymous speaker and the also untraceable representation of Eros. As seen in the previous section, that is also the case for most of the sixth-century AD poetic components collected by Planudes in the fourth section of his Anthologia, i.e., to be related to an actual work of art, even if in some cases the former is identified by the poet or somehow possible to acknowledge. The emphatic repetition of $\pi$ ov in line 1, and later twice in line 3, underlines the astonishment in face of an Eros unarmed and deprived of his wings, far from the classical representation of that winged and bitter god. As I shall be able to demonstrate in the next pages, along five elegiac couplets Marianus elevates an unarmed and garlanded Eros (vv. 1-6) to the image of the very Jesus Christ (vv. 7-10) within a complex wordplay of Platonizing background that mingles epic, lyric and religious dictions, a text that still lacks of a proper consideration.

9 More specifically in Heliopolis, Eros and Aphrodite were venerated with a licentious ceremony, as it seems to be implied both in APl 202 and 288. The negative formulation of the god's self-presentation, at the beginning, as well as the very argumentative structure of what I am not followed by what I truly am, could actually sustain Aubreton-Buffière's theory of $A P l 202$ as a textual parody of $A P l 201$.

10 E.g. Paus. 1.30.1, Phaedr. Fab. 255. Alternatively, Anteros was said to have arisen from the mutual love between Poseidon and Nerites (Ael., NA 14.28).

11 The exam of the woodcuts of some first editions reproduced in PLATE 2 still hides a meaningful detail. Figs. 1 and 2 show how the engravers simply forgot to cut the wings off, a mistake -in relation to the epigram - only to be corrected in Fig. 3, a re-impression of the first Parisian edition exemplified by Fig. 2. Furthermore, when comparing the last two versions of the engraving, it seems the same woodcut was used, as it was common for economical reasons. The images are perfectly identical. One can even note how, by shedding no paint on the wings, part of the right trunk of the background tree was lost, as a part of the wings remained at the right side of the child's head, next to the garland but clearly not part of it. 
The diction of the first part of the poem (lines 1-4), in spite of its accumulation of negative clauses, is the best identifier of the god. By asking for his traditional attributes, the ones he cannot found in the representation he sees, the first speaker evokes the traditional image of that god, as portrayed ever since pre-classical Greek art. The epithet given to the god's bow in line 1 ( $\pi \alpha \lambda$ iv $\tau$ tovov) provides the poem, at its very beginning, with a taste of Homer, as it is the same compound that often characterises Homeric bows (e.g. Il.8.266, 15.443; 10.459, Od. 21.11) ${ }^{12}$. The same flavour found in line 2, when the arrows are said to be made of reed, once again the case for the shafts of arrows in Homer (e.g. Il. 11.584). Nevertheless, at this point lyric and pastoral echoes are obvious, as the same word dóvakec (in plural) describes the shepherds' pipes already in Pindar ( $P$. 12.25), Aeschylus ( $P r .574)$ or even Theocritus (20.29), always in lyrical phrases that became very popular in the literate circles of Byzantium. Marianus thus starts by mingling the heroic and pastoral-lyric contexts, ultimately deciding for the last one, when giving the garlands (from line 4 onwards) a development at a time poetic, symbolic and, as I shall argue, political. Yet before, when the subject changes to the torch which the god traditionally stroked his victims with, the language keeps in the shadow the just-now mentioned arrows, as

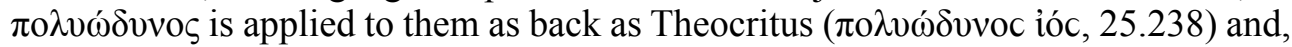
otherwise frequent among the Greek Anthology ${ }^{13}$, has a huge record of liturgical uses referring to the many pains and attachments of a human soul ${ }^{14}$. In one word, lines 1-3 of the epigram are filled with the unseen attributes of Eros, all of them presented as evil instruments united in a single purpose: give pain to mortals. Therefore, the ethical sublimation of that god, the epigram's poetical agenda, must replace such poetic and iconographic attributes by others, given later in the poem by the god himself, in the voice allowed to his plastic representation.

Only at the end of line 3 and in line 4 the poet mentions, still in the context of the interrogative clauses of lines 1-4, what he actually sees (and not what he expected to see, as until now) in the Eros he faces -the garlands, three in the hands, another one already over his forehead. At this point, diction carries the idea of Eros' empowerment, as the garlands function as ensigns of power ( $\chi \varepsilon \rho$ civ É $\chi \varepsilon 1 c ;^{\circ}$

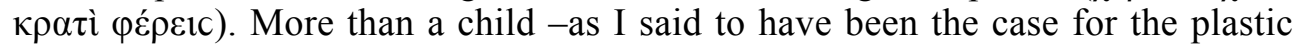
representation implied - vocabulary presents Eros as the main priest of some kind of mystery or religion, dressed up (in his nudity) with the attributes of his moral power. The formulation has once again Homeric soundings, as it recalls, for

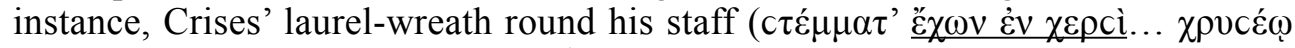

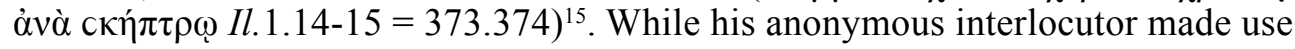
of the interrogative anaphora to identify the character portrayed in the work of art, Eros now starts by reinforcing in the negative clause that, once again, goes on defining what he is not $-\mathrm{a}$ silly answer to a silly question. When reading the

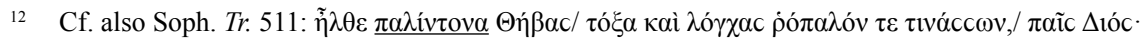

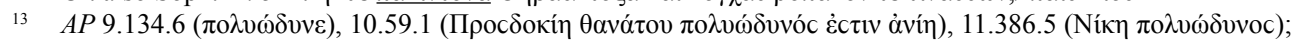

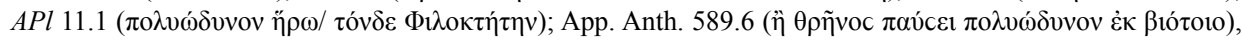

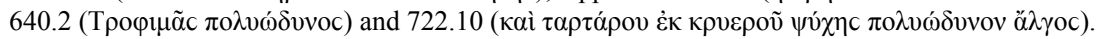

14 Only two examples, from the second half of the fourth century AD: Asterius of Amasea's Homiliae (1.7.1:

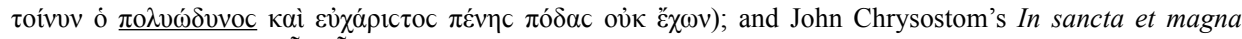

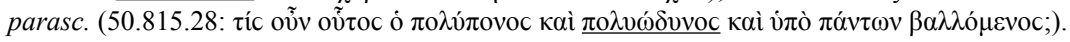

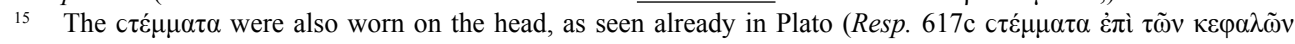
غ̇ðoúcac). 


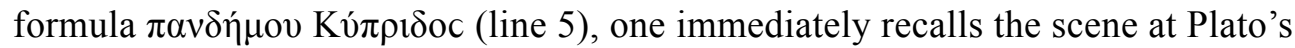
Symposium (180d-e) ${ }^{16}$ when Socrates explains the double nature of Aphrodite, and consequently Eros':

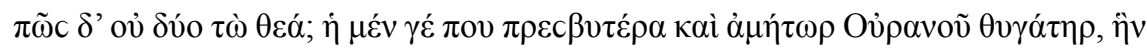

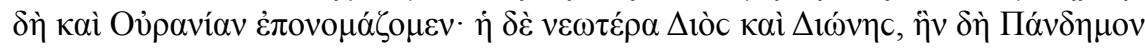

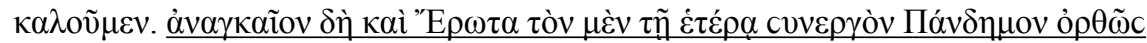

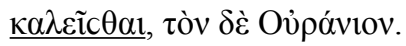

Does anyone doubt that she is double? Surely there is the elder, of no mother born, but daughter of Heaven, whence we name her Heavenly; while the younger was the child of Zeus and Dione, and her we call Popular. It follows then that of the two Loves also the one ought to be called Popular, as fellow-worker with the one of those goddesses, and the other Heavenly.

By denying to be the Eros $\pi \alpha v^{\prime} \delta \eta \mu c$, the everyday vulgar and carnal love, Marianus' Eros immediately raises himself above mortal nature of mankind and its promiscuous pleasures, therefore being a creature of heaven (ov̉ ' $\alpha \pi$ ò $\gamma \alpha$ ínc ciuì, lines 5-6), a divine being that raises both thought and soul towards spiritual world -the true Eros philosophus in the Platonic sense. On the other hand, while

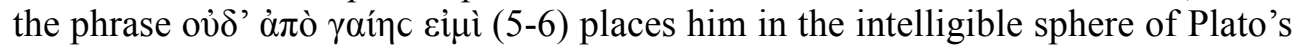
doctrine, any sixth-century AD reader would easily think of Jesus saying to his

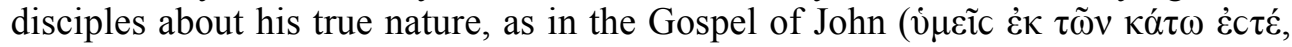

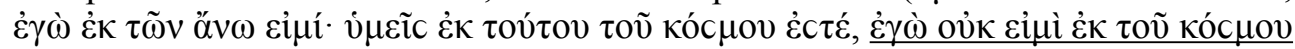

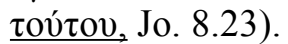

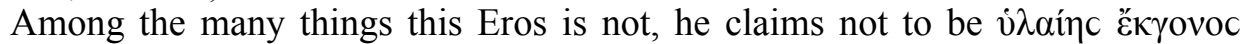

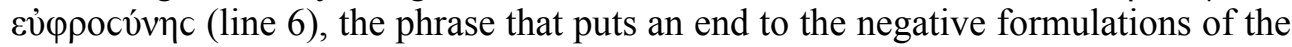
epigram. More than one hundred years ago, while looking precisely at lines 5-6 of the

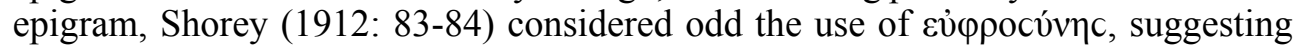
its correction for $\alpha \varphi \rho o c v ́ v \eta c$, a word he considered more suitable to describe the erotic pleasures of this Eros pandemos. The correction, as far as I know, was never considered for the editors of the Planudea or even included in the apparatus of the

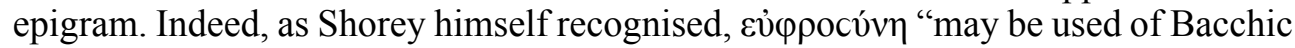
and convivial hilarity and blithesomeness, as opposed to care and worry", and such

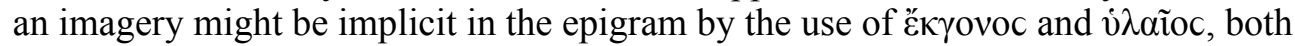
related to a context of wilderness, as in Theocritus ( $\theta \dot{\eta} \rho$ vं $\lambda \alpha \tilde{i} o c$ 23.10). Furthermore, vं$\lambda \alpha \tilde{i o c}$ is used by Proclus (fifth century AD) as the opposite of $\dot{\varepsilon} \mu \pi v \dot{\rho} \rho 10 c$ and $\alpha i \theta \dot{\varepsilon} \rho 10 c$, so that it must be a commonplace for referring to the Platonic sensitive sphere by the time the epigram was written ${ }^{17}$.

Lines 7-8 sound like a public proclamation, as the speaking Eros is willing to unequivocally explain his true nature. Once again, diction is at first sight Platonizing. Eros is the agent of the Platonic asceticism "toward an immortality freed from the

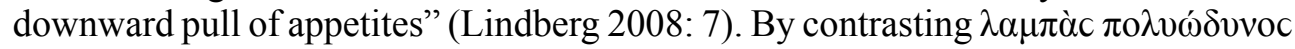

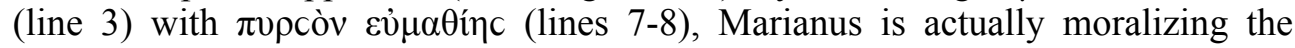

Cf. also Pl. Symp. 181c and Xen. Smp. 8.9.

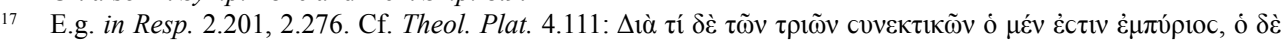

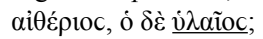


pagan attributes of Aphrodite's son, from the many pains of erotic pleasure into the true knowledge of the Logos -a different kind of inflammation for a different kind of love. The compound $\varepsilon \dot{u} \mu \alpha \theta i \alpha$, to be found once in the writings of Cyril ${ }^{18}$ (Patriarch of Alexandria from 412 to 444 AD), is indeed a commonplace in Platonic

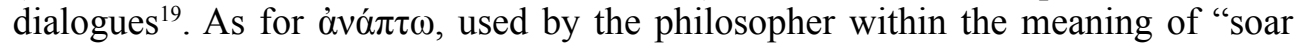
up" (from the sensitive world into that of the idea ${ }^{20}$ ), it has in the epigram the sense of "light up" (or even "inflame"), in what constitutes its most frequent assumption in Christian writings, as in the case of John Chrysostom (ca. 349-407) ${ }^{21}$ or, later in the twelfth century, John Scylitzes ${ }^{22}$. To express the idea of ascension in virtue and knowledge, the poet prefers another verb, in a phrase that could be considered the

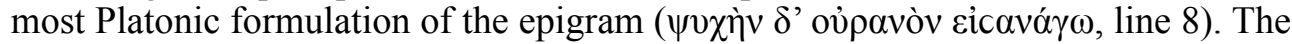
fact is sicavó $\gamma \omega$ is not a frequent verb in the Greek texts that came down to us. One can first read it in the Odyssey (8.529), where it refers to a woman's grief being lead

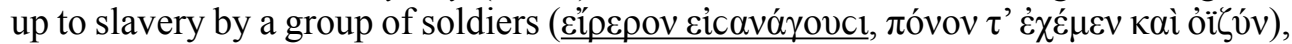
within the simile given for Ulisses' grief when hearing the blind aedo singing his own story ${ }^{23}$. Therefore, my suggestion would be that Marianus somehow substituted

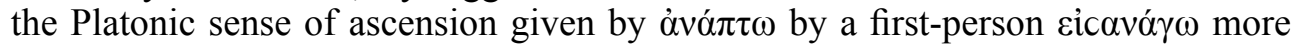
directly related to the reverse of the Homeric idea of "lead up into slavery", truly meaningful both to Plato ${ }^{24}$ and the Christians.

In the final couplet, when Eros answers the question posed to him back in lines

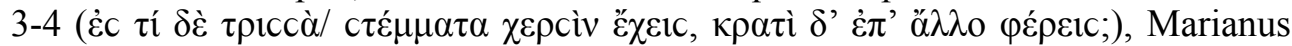
depicts an Eros caught by the artist at the end of weaving four garlands, one for

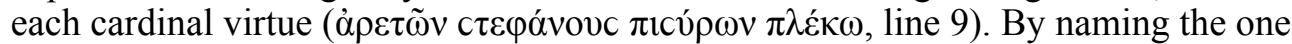

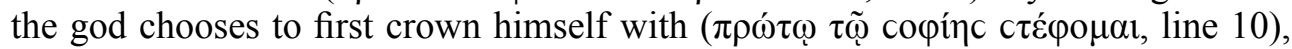
the poet is following the original Platonic list of virtues, as discussed in the book four of the Republic (426-435). They are, in Platonic moral, the attributes of a good

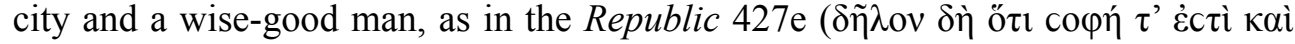

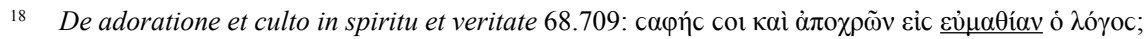

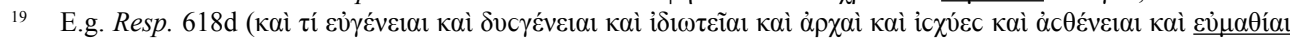

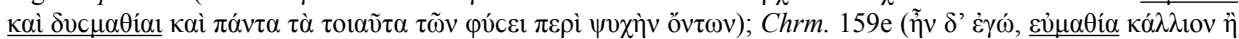

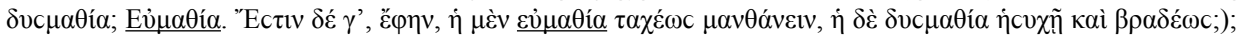

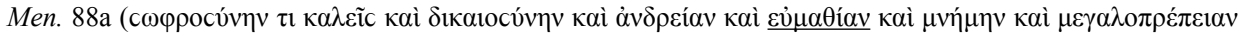

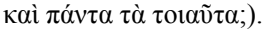

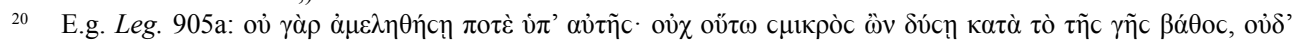

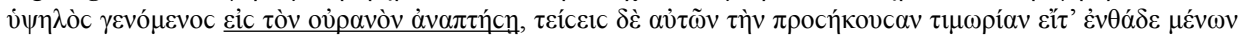

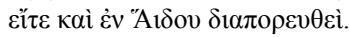

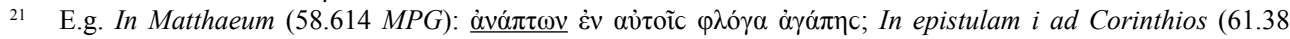

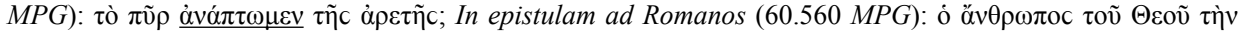

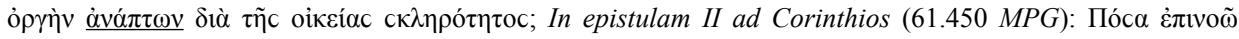

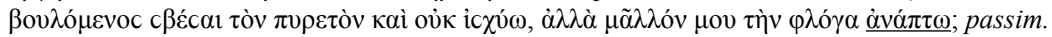

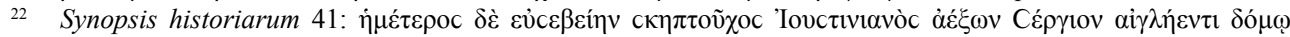

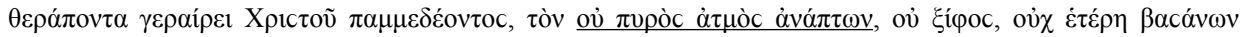

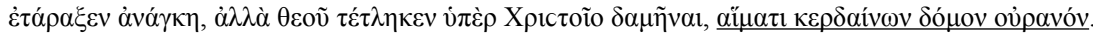

23 The Homeric simile, and especially the interpretation of the expression sípepov cicavófovcr (v. 29), were commented by Apollonius' Lexicon Homericum (first century AD) and Eustathius' Commentary on the Odyssey (late twelfth century AD), besides being reshaped twice by Triphiodorus' Destruction of Troy in lines 138 ('I $\lambda_{10} \mathrm{~V}$

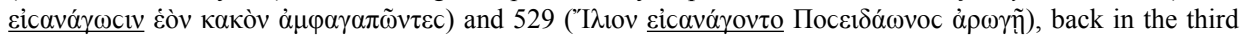
century AD.

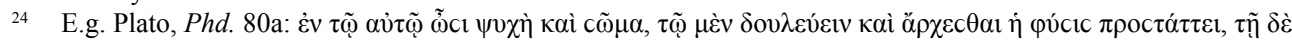

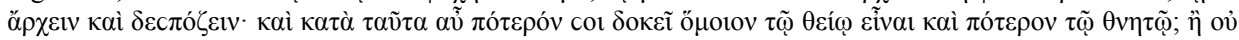

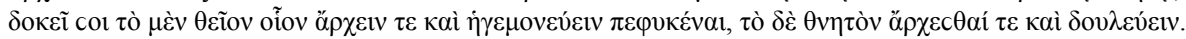




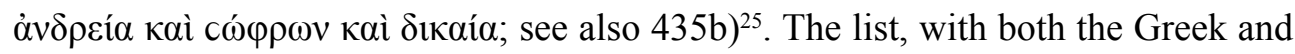
Latin words for each virtue, can be thus resumed: prudence, or wisdom ( $\varphi$ póvๆcic;

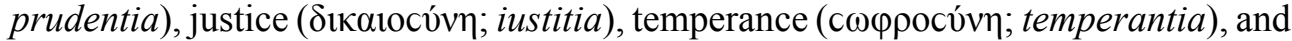
courage ( $\dot{\alpha} v \delta \rho \varepsilon i ́ \alpha ;$ fortitudo). The exact same list, where copí $\alpha$ (or its more frequent equivalent, $\varphi \rho o ́ v \eta c ı c)$ always occupies the first place, was followed by Biblical and Christian traditions. That is the case, in Greek, for the Septuagint's version of the Wisdom of Solomon ${ }^{26}$ or Theodoret of Cyrus ${ }^{27}$ (first half of the fifth century AD); and, in Latin, St. Ambrose ${ }^{28}$ (ca. 330-397 AD), the first Christian author to mention them as so, alongside St. Augustine ${ }^{29}$. Besides the abovementioned passages of the

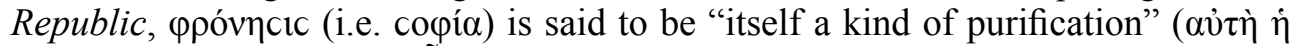

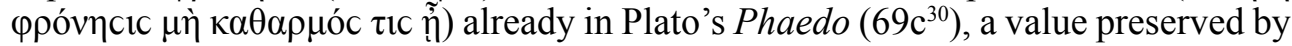
main Christian writers.

Christianity soon made sophia -often personified as an icon ${ }^{31}$ - the mediator between the mortal soul in mankind and the divine (God himself), an attribute and companion of Christ (the incarnate Logos) ${ }^{32}$. The proliferation of Byzantine churches devoted to Hagia Sophia, which Brzozowska (2012: 85-96) recently confirmed to be so-titled as signifying the Son of God, could be an evidence itself. Another clue could be the late sixth or early-seventh century John Climacus' Scala Coeli, where wisdom (a Temple, i.e. Christ) commands a soul "attached to the shepherd" (chap. 28). Climacus' most direct source is of course the ladder that appeared to Jacob in a dream (Gen. 28.12), a ladder "touching the sky" through which "messengers of God went up and down". Nonetheless, also this Jewish image of ascension through purification is easily related to Plato, if only one recalls Diotima's words in the Symposium (211c) on "mounting the heavenly ladder, stepping from rung to rung...

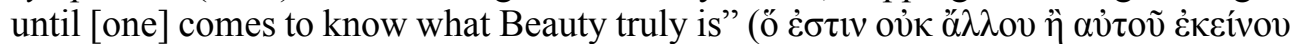

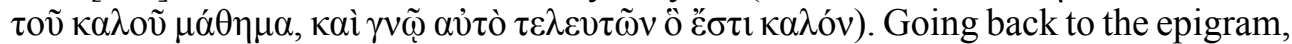
and to sum up, one can say that Eros, when crowning himself first with the garland

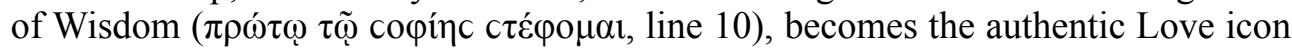
(both literary and pictorial), a metaphor of the incarnate Logos, Jesus Christ himself, he who actually leads up the way to the Father and is himself the ladder that anyone aiming for salvation must cline ('E

25 Increased in number by Aristotle (Rhet. 1366b), Cicero (first half of the first century BC) once again limited their number to four (Nam virtus est animi habitus naturae modo atque rationi consentaneus. Quamobrem omnibus eius partibus cognitis tota vis erit simplicis honestatis considerata. Habet igitur partes quattuor: prudentiam, iustitiam, fortitudinem, temperantiam: Inv. Rhet. 2.159).

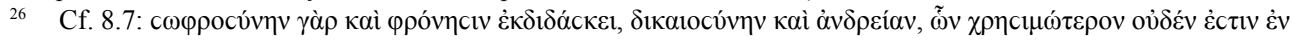

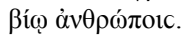

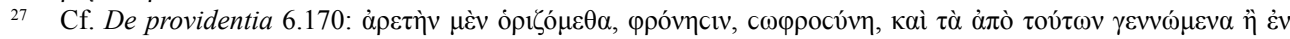

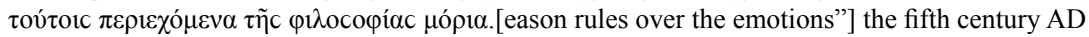

28 In Lc. 5.62: Et quidem scimus virtutes esse quatuor cardinales, temperantiam, justitiam, prudentiam, fortitudinem.

29 De moribus Ecclesiae catholicae 1.15.25: Itaque illas quattuor virtutes, quarum utinam ita in mentibus vis ut nomina in ore sunt omnium, sic etiam definire non dubitem, ut temperantia sit amor integrum se praebens ei quod amatur, fortitudo amor facile tolerans omnia propter quod amatur, iustitia amor soli amato serviens et propterea recte dominans, prudentia amor ea quibus adiuvatur ab eis quibus impeditur sagaciter seligens.

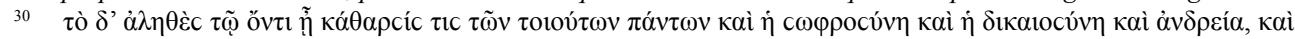

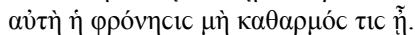

31 AP 1.93 -anonymous in all manuscripts but ascribed to Gregorius of Nanzianzus (IV cent. AD) - is said by the lemma to be the copy of an inscription for a portrait of the four Virtues (no names mentioned) at the Church of Saint Basil in Caesarea.

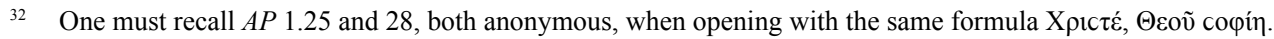




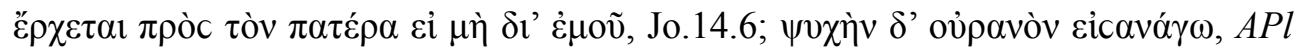
201.8).

I believe that a bridal context must also be pointed out, more specifically in relation to the biblical parable of the wise and imprudent virgins seeking to marry the Lord (Mt. 25). While the garland-weaving task of the epigram might himself suggest the preparation of a wedding, the presence of the light element in both the

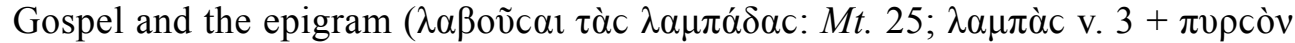
v. 7) create a similar night context for both texts, alongside the use of $\dot{\alpha} v \alpha$ á $\tau \omega$ within its Christian assumption of "lighten up", as seen before. Finally, the underlying of sophia's role in Marianus can easily be related to the character of five of the parable's virgins, said to be póvuor, in spite of the poet's programmatic use of the equivalent

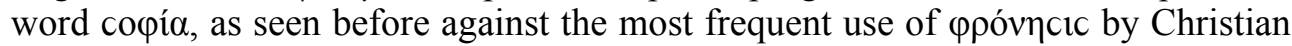

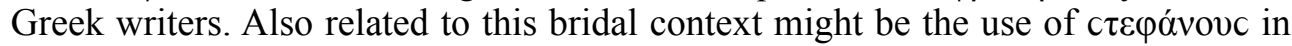

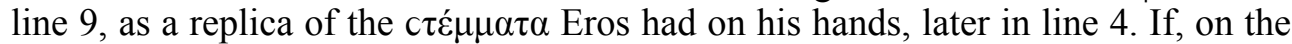

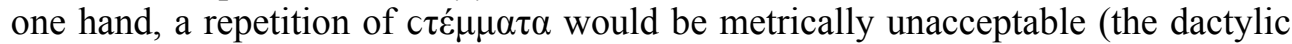
nature of the word is inadmissible after the syncope of the pentameter), on the other hand the choice for c $\tau \varepsilon \varphi \alpha ́ v o v c^{33}$, alongside the verb $\pi \lambda \varepsilon \dot{\kappa} \kappa \omega$ ("to weave"), may also symbolise the poetic harbour of Marianus, within the old tradition of referring to it by the metaphor of the garland weaving ${ }^{34}$.

A great deal of work has been done as for the recast of Plato's philosophy (particularly the mythology of Eros) in Byzantium and its transformation into what Lindberg (2008: 7) called "teleology of Love". While dismissing further on that subject, the truth is the Fathers of the Church and other Christian writers soon made their own the Platonic theories of ascent and purification, especially after the allegorical interpretations of the Alexandrian school of Clement and Origen and the Neo-Platonic synthesis of Plotinus ${ }^{35}$. In one word, and to sum up our symbolic understanding of the epigram, both the ancient god of Love and Jesus fell from the sky -and that is why Marianus' Eros has no longer wings - and came to live within the humans to raise their souls up to the Father, by means of inflaming them with true wisdom.

\section{Marianus, Justin and Sophia's wisdom}

My reading of $A P l .201$ as a Christian poem commissioned by Justin II and Sophia demands an answer for at least two questions. One, is it possible to see the epigram as the work of an epigrammatist self-advertising by the image of the garland weaving? And two, can wisdom (the virtue) stand for a very specific female reference named Wisdom as well?

33 Long before being an image of poetic labour and poetic collections, garlands were a very rich poetical expedient, namely in the formation of several epithets, back from the Homeric Poems. See Martins de Jesus (2009: 31-57).

34 The most striking example (but not the oldest one known) is surely Meleager's Preface to his epigrammatic Garland, in the first century AD (AP 4.1). On this 58 lines introductory poem, see Cameron (1993: $5 \mathrm{ff}$.), Argentieri (2007: 147-164) and Martins de Jesus (2016: 176-179). According to Gutzwiller (1998: 79), "Nossis deserves credit for first extending the metaphor of poetry as flowers to collected works [even if] both Sappho (55.2-3 PLF) and Pindar (Ol. 6.105; cf. 9.27) had used the metaphor of song as flower, and the image of poet as bee had become explicit in Plato's Ion (534a-b)".

35 For an overview of this subject and the main bibliography see Patten (2013: 2-18). 
Avril Cameron's 1980 paper shed light on Justin's patronage of statuary and buildings as part of his political propaganda, besides referring (p. 68) to the several contemporary epigrams of the Greek Anthology that must have celebrated such works of art and architecture. Furthermore, it is nowadays commonly accepted, especially after both Camerons' paper (1966a: 6), that the Cycle of Agathias (the epigrammatic collection from where $A P l 201$ was copied by Planudes) was published during the reign of Justin II and not Justinian's, his uncle and predecessor. As the Cycle only contains contemporary poets, Marianus must himself be considered a contemporary and famous epigrammatist, famous enough to justify his inclusion in Agathias' collection with no less than six components. Such an understanding might also be reinforced by the lack of any patronymic or adjective next to his first name, none besides the "humble" 36 Scholastichus; i.e., the poet must be famous enough to be identified without further details. Impossible as it is to fully stand for the direct propagandistic commission and purpose of the epigram, as it has been shown to be case of $\mathrm{APl} \mathrm{72}{ }^{37}$, evidences were able to trace some coincidences between the epigram, Marianus' other poems and the information available in relation to Justin II and Sophia's reign.

In order to discuss the poem's circumstances, I believe it is necessary to glance at the other five epigrams ascribed to Marianus by Planudes. AP 9.657 is nowadays accepted to be a dedicatory epigram for the opening show of the Sophianae, a palace in the suburb of Constantinople (one of many named after the empress) that, according to Avril Cameron (1967: 11-13) ${ }^{38}$, must have been built around 565 and completed not later then 566-567. ${ }^{39}$ As for $A P l$ 201, one possibility would be that it was originally the commissioned inscription for a work of art of Eros identifiable as Christ, placed at some important room of that palace. On the other hand, it is tempting to relate it also with the context of other two epigrams of Marianus on the figure of $\operatorname{Eros}^{40}\left(A P\right.$ 9.626-627), often assumed ${ }^{41}$ to be the ecphrasis of works of art that used to decorate the halls of some unidentified bath-complex in Constantinople. Rather warming-up the waters with his torch $(\lambda \alpha \mu \pi \alpha \dot{\alpha} \delta \mathrm{r}$ 9.626.2) in one painting, or having left it out with the Nymphs for the sleeping moment portrayed in the other $(\lambda \alpha \mu \pi \alpha \dot{\delta} \alpha$ 9.627.2), somehow the torch is there, the same one whose absence is noticed by the

36 The adjective is Geiger's (2009: 114).

37 The epigram, ascribed to Agathias, commemorates the victories over the Persians and might have been inscribed at the base of a statue of Justin II. See Av. and A. Cameron (1966b).

38 See also Av. and A. Cameron 1966a: 21

39 The poem, in all manuscripts attributed to Marianus, was for long ascribed to Agathias (e.g. Waltz-Soury 1974, repr. 2002: 128, n. 1, 287) and only later to the "Marianus Scholasticus" of the manuscript tradition, first by Avril and Alan Cameron (1966a: 17, 21), and later by each one of them separately (Av. Cameron 1967: 15-16, 1976: 134; A. Cameron 1993: 70-72). The fact is Marianus used to be identified with Marianus of Eleutheropolis, according to the Suda a consul, prefect and patrician under the emperorship of Anastasius (491-518), mostly an author of iambic poetry (on him, see Geiger 2009). Therefore, $A P 9.657$ (previous to 567 AD) could not be attributed to him in observance of chronology, and that is also the reason why Zonaras (Annales 14.10), quoting the epigram already in the twelfth century, wrongly attributed it to Agathias, the poet and the editor of the Cycle where it was first collected, not after 567/568 (Av. and A. Cameron 1966a: 6 ff.; idem 1967: ff.). For a synthesis of the history of attribution, see Geiger (2009: 113-114).

40 There can be a relation between the garland-weaving metaphor of $A P l 201$ and the "hypothetical collection on the subject of Eros" suggested by Geiger (2009: 114), based on the fact that five of the six epigrams ascribed to Marianus are on that god ( $A P$ 9. 626-627, 668-669, $A P l 201)$. It is thus tempting to ask: can line 9 of number 201 somehow suggest a personal anthology of poems on love by Marianus, one that Agathias might be aware of?

41 E.g. by Aubreton-Buffière (1980, repr. 2002: 282). 
speaker of $A P l 201$ ( $\pi$ oṽ $\lambda \alpha \mu \pi \alpha ̀ c ~ \pi o \lambda v \omega ́ \delta v v o c ;$ line 3). While there is no actual proof for the inscription of any of these epigrams -one may think of the poet composing himself on the works of art already in situ and accessible to locals and visitors -, the graphic model of $A P l 201$ could have decorated a more private or official room of the complex, one meant for receptions and even visitors, where, not losing entirely the Eros (and Aphrodite)-motif of the decoration, some intentional ambiguity would still reinforce the religious commitment to orthodox Christianity pursued by Justin II and Sophia. In fact, the couple - and particularly Sophia - lived and reigned under suspicions of monophysetism ${ }^{42}$, having therefore to use official artistic commission as a means of self-advertising their orthodoxy.

This theory finds some foundations when confronted with several aspects of the reign of Justin II and, particularly, his wife's role in it. As mentioned in section I, Planudes, still in the first half of the fourteenth century, commented, supra lineam

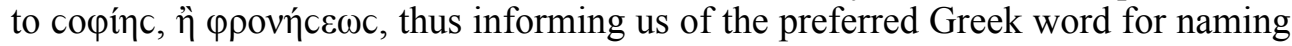
that virtue $e^{43}$. If so, the choice for the word copín could actually aim for a reference to the empress. Probably self-committed to the motif of Eros and Aphrodite (to the point of choosing them to decorate the Baths named after her?), she would also get some religious publicity by the assimilation of the love-god of the Ancients with Christ - and consequently, of herself with the wisest of the brides.

Corippus, the official poet of Justin II's court ${ }^{44}$, often translated her Greek name Copía to its Latin equivalent Sapientia, a word used both as a divine name and a title for the empress. He even tried to give Justin some credit for the existence of the very Hagia Sophia, when playing with the name of the church and the name of the new empress ${ }^{45}$. That the identification of both sophiae was part of the official agenda can still be seen in a small epigram ( $A P$ 9.813), anonymous in the manuscripts but ascribed by scholars to Cyrus (said "the ex-consul")

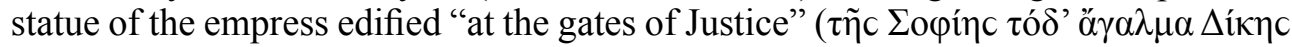
$\pi \rho \circ \pi \alpha$ ó $\theta \varepsilon \theta 0 \rho \alpha \dot{\alpha} \omega v)$, i.e. a courthouse ${ }^{47}$, a poem where both the empress and Justice (the cardinal virtue) are proudly deified.

Sophia, the niece of the also great empress Theodora, was as her aunt no common empress. She played an important role, both religious and political, right from before Justin's ascension to throne -which she probably helped to happened - until the final years of his reign, when madness already tormented her husband ${ }^{48}$. A great deal of buildings, statues and other honours were given to her ${ }^{49}$, the first empress to appear in Byzantine coins alongside the emperor. As conveniently stated by Avril Cameron

42 See the testimonies, among others, of John of Ephesus (HE 2.10) and Syrian (Chron. 10.7). See Av. Cameron (1975: 7-16) and Garland (1999: 44-47). The last scholar (1999: 45) interprets the prayer to Mary spoken by Sophia in Corippus' poem (Iust. 2.52-69 = Av. Cameron 1976: 82-83), when stressing the divine nature of Christ, as "no discomfort to one who had monophysite leanings but who wished to appear unquestionably orthodox".

43 See supra, notes 25-26.

44 See Av. Cameron (1976: 1, 10-12).

45 Iust. 1.280: rem Sophiam dignam certo sapientia fecit. I cannot go as far as Garland (1999: 41), when saying this evidence, among the many encomiastic words of Corippus in that poem, mean that "she is the patroness and that he is fulfilling her wishes in writing the poem".

46 On this Cyrus, see A. Cameron (1982, repr. A. Cameron 2015: 37-80), who dates the poem from 566/567.

47 The anonymous $A P 9.812$ informs that a statue of Justin II was also erected next to Sophia's.

48 For the personal, political and religious data (most of them controversies) on Sophia, see Av. Cameron (1975: 5-21), Garland (1999: 40-57) and Zarini (2012: 1-13).

49 Cf. Av. Cameron (1967, 1975, and 1980). 
(1975: 11), "it was essential for poets of the day to pay as much attention to the empress as to the emperor". With that in mind, I believe to have shown the possibility of not one but two epigrams of Marianus composed under imperial commission or at least imperial encomiast purposes: AP 9.657 (on the Sophianae) and APl 201.

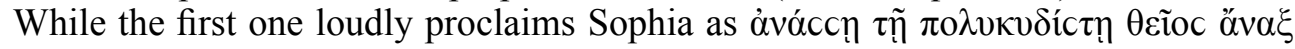
(lines 3-4), the second would have been meant as a more enigmatic poem for, I foresee, an official or somehow more private space. If Geiger (2009: 114) is correct when suggesting "a hypothetical collection on the subject of Eros" organized by Marianus - a probable theory, if one only thinks on Agathias knowing and using such a collection for the making of his own -, that could actually lead us into the clue of the empress' direct commission of $A P l 201$ and the other aforementioned epigrams on Eros, among several others that most probably did not came down to us.

\section{Bibliography}

Argentieri, L. (2007), “Meleager and Philip as epigram collectors”. In: Bing, P., Bruss, J. S. (2007: 147-164).

Aubreton, R.; Buffière, F. (1980, repr. 2002), Anthologie Grecque. Tome XIII. Anthologie de Planude. Paris, Les Belles Lettres.

Bassett, S. (2004), The urban image of Late-Antique Constantinople. Cambridge, Cambridge University Press.

Bing, P.; Bruss, J. S. (2007), Brill's Companion to Hellenistic Epigram down to Philip. Leiden, Brill.

Brzozowska, Z. (2012), "The Church of Divine Wisdom or of Christ - the Incarnate Logos? Dedication of Hagia Sophia in Constantinople in the light of Byzantine sources from $5^{\text {th }}$ to $14^{\text {th }}$ century", Studia Ceranea $2: 85-96$.

Cameron, A. (1982), "The empress and the poet: paganism and politics at the court of Theodosius II", Yale Classical Studies 27: 217-290. Reprinted in Cameron, A. (2015: 37-80).

- (1993), The Greek Anthology. From Meleager to Planudes. Oxford, Oxford University Press.

- (2015), Wandering Poets and other essays on Late Greek literature and philosophy. Oxford, Oxford University Press.

Cameron, Av. (1967), "Notes on the Sophiae, the Sophianae and the Harbour of Sophia", Byzantion 37:11-20.

- (1975), “The Empress Sophia”, Byzantion 45: 5-21.

- (1976), Flavius Cresconius Corippus. In laudem Iustini Augusti minoris. Ed. with translation and commentary. London, The Athlone Press.

Cameron, Av.; Cameron, A. (1966a), “The Cycle of Agathias”, JHS 86: 6-25.

Cameron, Av., Cameron, A. (1966b), “Anth. Plan. 72: a propaganda poem from the reign of Justin II”, Bulletin of the Institute of Classical Studies 13: 101-104.

Cameron, Av. (1980), “The artistic patronage of Justin II", Byzantion 50: 62-84.

Dübner, F. (1872), Epigrammatum anthologia palatina cum Planudeis et appendice nova... Vol. 2. Paris, Firmin Didot.

Garland, L. (1999), Byzantine Empresses. Women and power in Byzantium, AD 527-1204. London, New York.

Geiger, J. (2009), “Marianus of Eleutheropolis”, Scripta Classica Israelica 28: 113-116. 
Gutzwiller, K. (1998), Poetic Garlands. Hellenistic Epigrams in Context. Berkeley, Los Angeles: University of California Press.

Lindberg, C. (2008), Love: a brief history through Western Christianity. Oxford, Blackwell.

Männlein-Robert, I. (2007), "Epigrams on art. Voice and voicelessness in ecphrastic epigram", in Bing-Bruss 2007: 251-271.

Martins de Jesus, C. A. (2009), "Grinaldas de violetas. Epítetos derivados de tov e suas valências na poesia grega", Humanitas 61: 31-57.

- (2014), "The statuary collection held at the Baths of Zeuxippus (AP 2) and the search for Constantine's museological intentions", Synthesis 21: 15-30.

- (2016), "Meleagro e a linguagem das flores. Tradução comentada de AP 4.1", Organon 31: 171-186.

McCann, A. M. (1978), Roman Sarcophagi in the Metropolitan Museum of Art. New York, The Metropolitan Museum of Art.

Patten, T. (2013), "The purification of Love: heavenly ascent from Plato to Dante", Intermountain West Journal of Religious Studies 4.1: 2-45.

Pfrommer, M. (1980), "Ein Eros des Praxiteles", AA 95: 532-544.

Shorey, P. (1912), "Note on Anth. Pal. XVI.201.5-6 (Didot), CP 7.1: 83-84.

Toynbee, J. M. C. (1934), The Hadrianic School. Cambridge, Cambridge University Press.

Waltz, P., Soury, G. (1974, repr. 2002), Anthologie Grècque. Anthologie Palatine Tome VIII (Livre IX, épigrammes 359-827). Paris, Les Belles Lettres.

Zarini, V. (2012), “L'éloge de l'empereur Justin II et de l'impératrice Sophie chez Corippe et chez Venance Fortunat (Poèmes, Appendice, 2)", Camenae 11: 1-13. 


\section{Plate I}

\section{EROS IN ROMAN IMPERIAL ART}

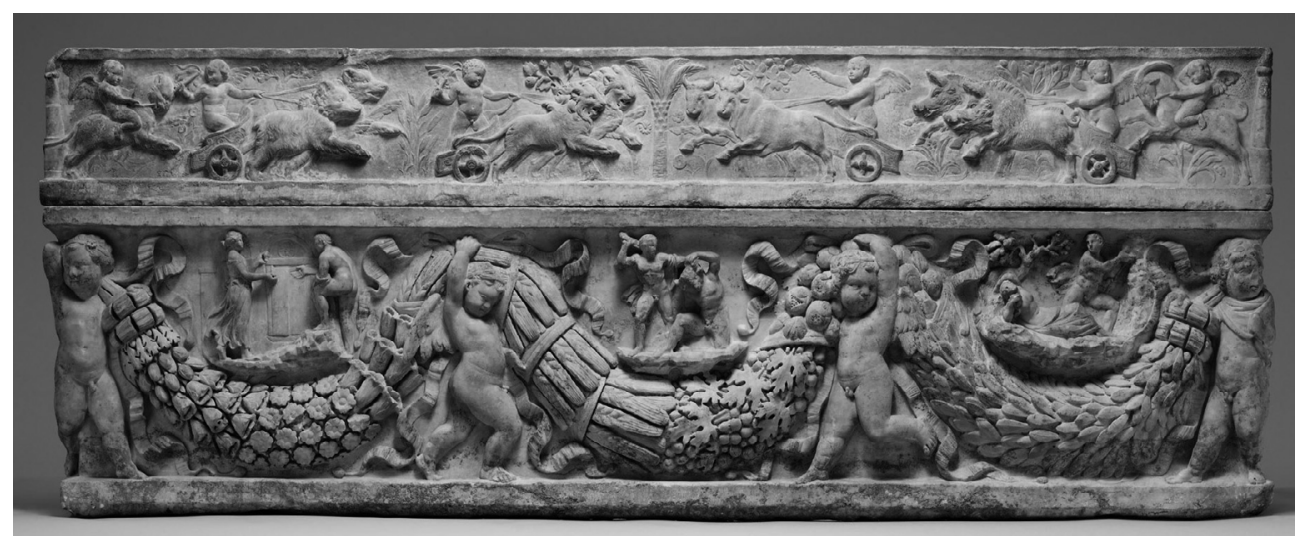

Fig. 1. Garland sarcophagus. Early-Antonine (ca. 140-150 AD). New York, The Metropolitan Museum of Art, inv. 90.12. [McCann 1978: 25-26]
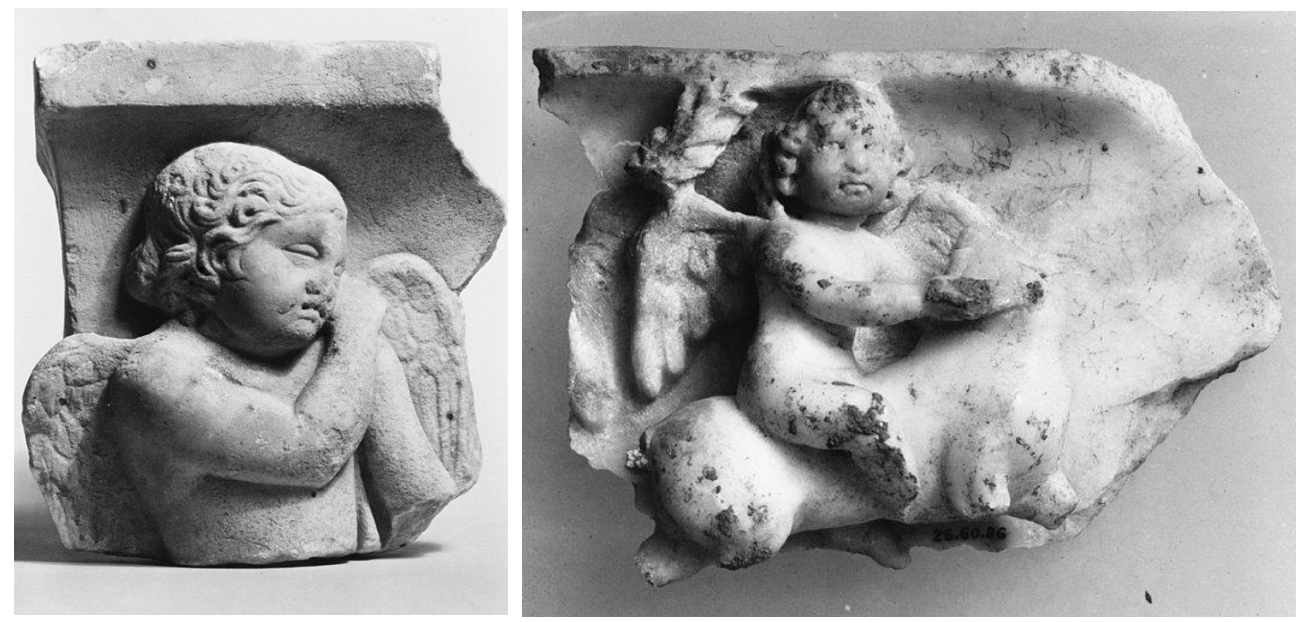

Fig. 2 [left]. Roman marble sarcophagus fragment: Eros with a torch. Third quarter of the second century AD (Mid-Antonine). New York, The Metropolitan Museum of Art, inv. 49.101.16. [McCann 1978: 51-52]

Fig. 3 [right]. Roman marble sarcophagus fragment: Eros mounted in a horse. First half of the third century AD (Severan). New York,

The Metropolitan Museum of Art, inv. 26.60.86. [McCann 1978: 85] 


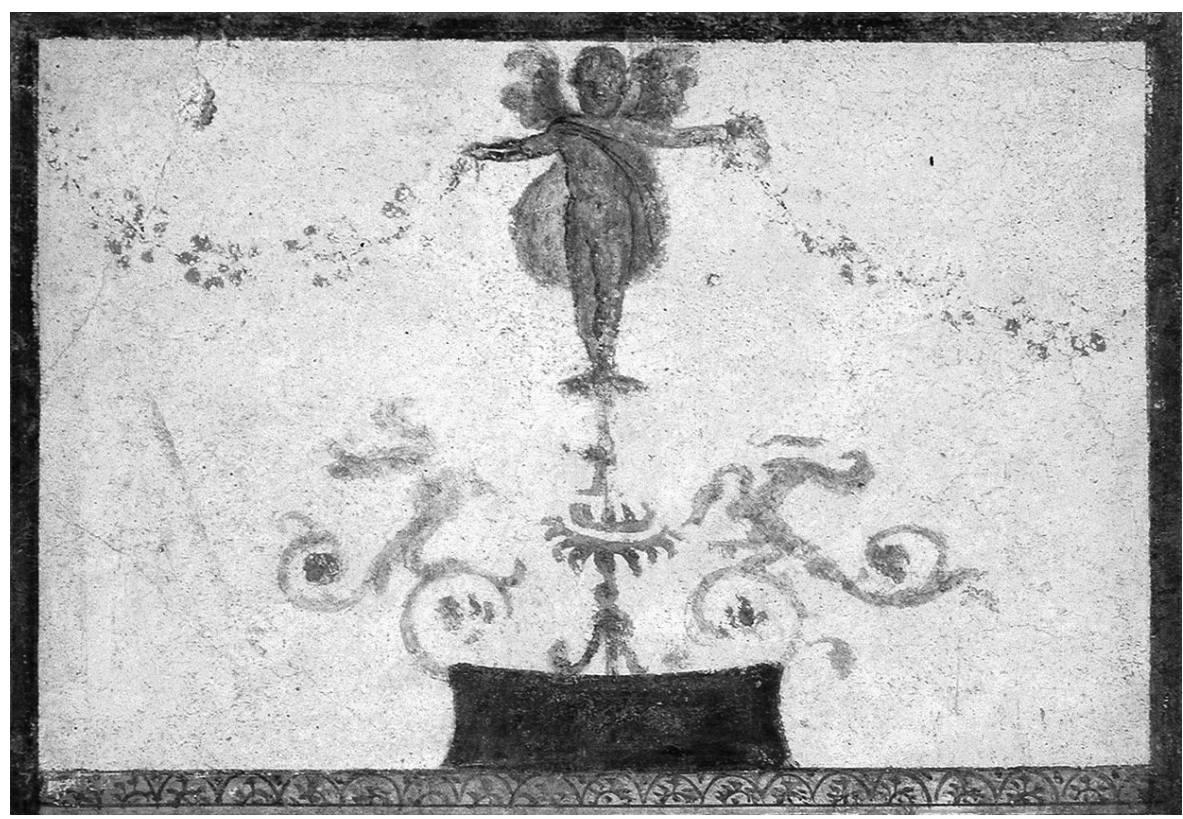

Fig. 4. Crowned Eros with garlands. Fresco from the House of the Trojan Sacellum in Pompeii. Second style, ca. 80-20 BC.

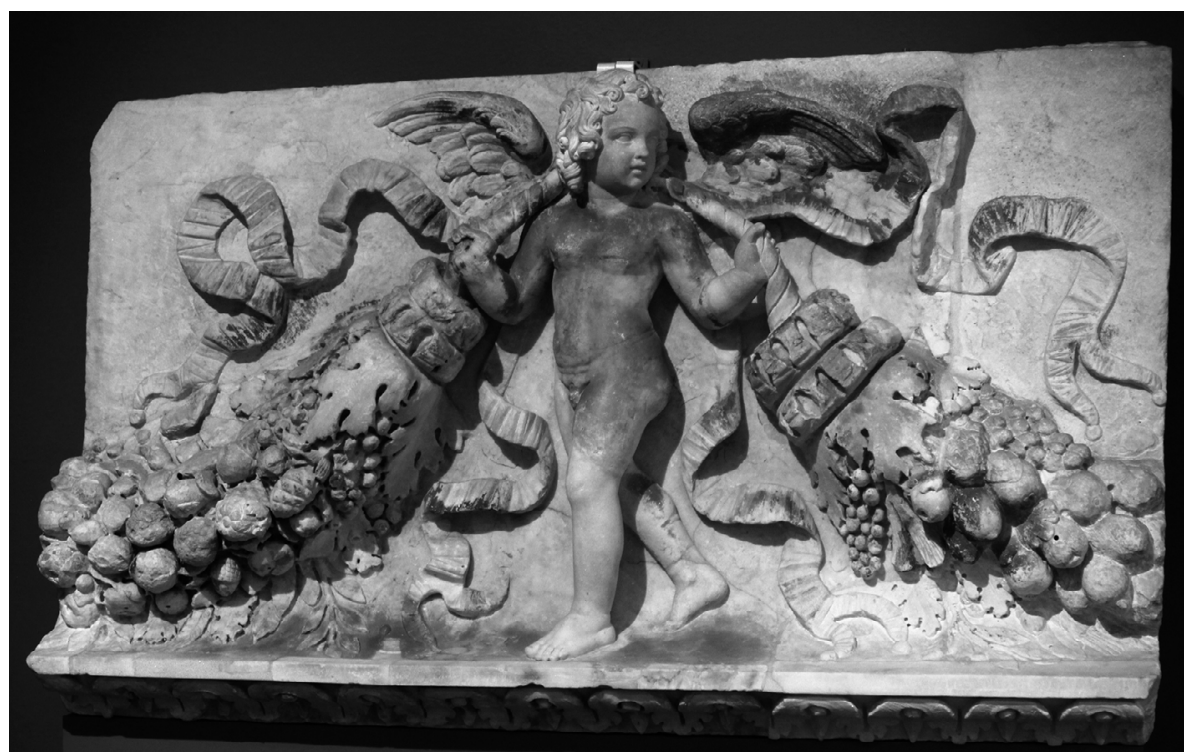

Fig. 5. Eros and two garlands of flowers and fruits. Fragment of a marble frieze, probably from the Forum of Trajanus, from c.113-117 AD. Berlin, Staatliche Museum Antikensammlungen, inv. Sk 902. 


\section{Plate II}

\section{Alciato’s emblem 70}

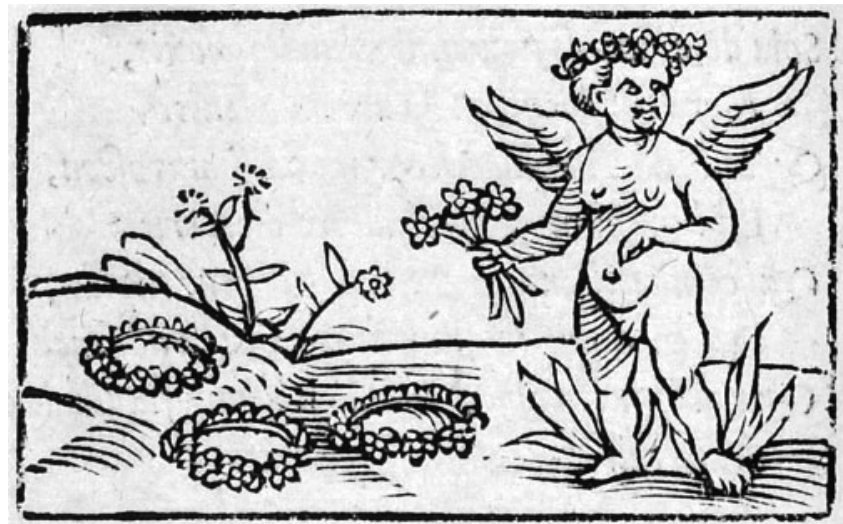

Fig. 1. Emblematum liber. Augsburg, 1531 (ed. princeps)
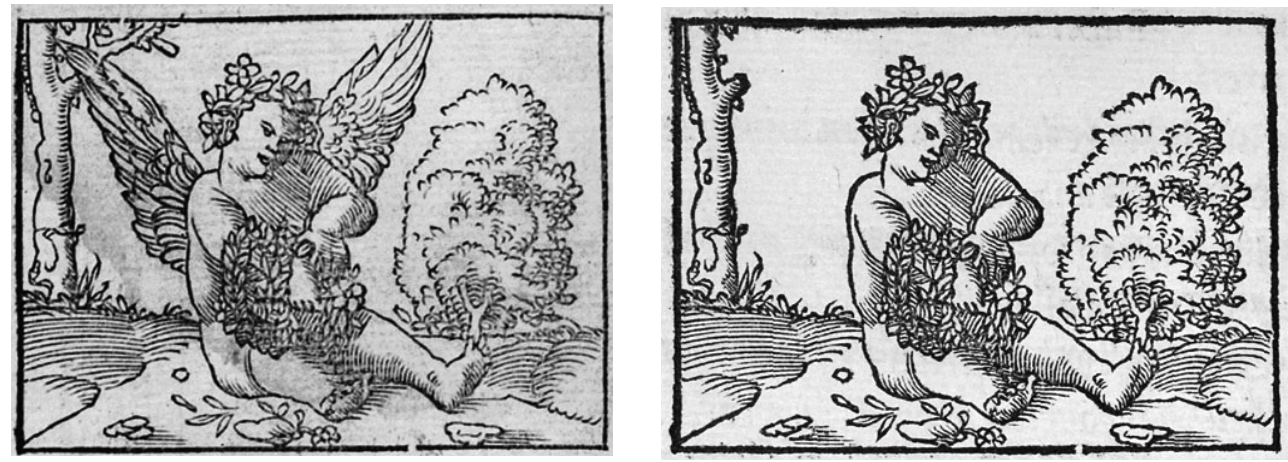

Fig. 2. Emblematum libellous. Paris, 1534.

Fig. 3. Emblematum libellous. Paris, 1542. 